\title{
STRATEGIC MANAGEMENT TOOLS AS A PREREQUISITE FOR MAINTAINING COMPETITIVENESS IN THE SLOVAK HOTEL INDUSTRY
}

\author{
Alžbeta Királ'ová ${ }^{1}$ \\ Andrej Malachovský2 (i)
}

DOI: https://doi.org/10.31410/tmt.2019.1

\begin{abstract}
The paper focuses on the application of modern strategic management tools in the Slovak hotel industry. It aims to identify the level of utilization of the management tools in hotels in Slovakia. The study evaluates the application of modern management tools using mathematical and statistical methods, including mean values and standard deviation. The result of the research indicates that hotels in Slovakia do not utilize the possibilities the strategic management tools offer mostly because the hotel managers significantly lacked relevant knowledge of these tools. The results demonstrate that the most used strategic management tools in monitored hotels include Customer Relationship Management and Strategic Planning, followed by Internal Relationship Management, Controlling, Outsourcing, Benchmarking, Social Media, and Supplier Relationship Management, respectively. The findings of this study can help to maximize the full potential of hotels and improve their competitiveness by creating awareness of the importance and usage of strategic management tools.
\end{abstract}

Keywords: Hotel Industry, Management, Strategic Management Tools, Competitiveness, Slovakia.

\section{INTRODUCTION}

$\mathrm{T}$ he business represents an environment in which strategic management tools, methods, and concepts are created to help managers achieving business goals. From change, the creation of added value, support for development and growth of enterprises as well as the whole economy, management tools are closely linked to innovation and competitiveness as innovations are considered the primary engines of development and competitiveness. Consequently, it is also necessary for hotels to continually look for growth opportunities and apply strategic management tools as the highly competitive global tourism market and economic turbulence has increased the challenges managers face whether they are trying to boost revenues, innovate, and improve quality, increase efficiencies or plan for the future. If the managers have a clear perception, they understand the strategic management tools and use them correctly; these tools can help them deal with complexities and uncertainties, improve the performance and efficiency of the hotel (Wright, Paroutis \& Blettner, 2013; Kotler, Berger \& Bickhoff, 2015; Afonina \& Chalupský, 2012).

Strategic management tools refer to a set of predefined activities and procedures designed to help managers facilitate strategy and achieving the predetermined goals, cope with changes in customer behavior, ensure a competitive position, and improve business performance (Stenfors et al., 2007; Stonehouse \& Pemberton, 2002). The importance of the application of these tools into management activities is undeniable because of the changing business environment, including new trends, theory, and practice in management.

\footnotetext{
$1 \quad$ College of Regional Development and Banking Institute - AMBIS, a. s., Lindnerova575/1, 18000 Praha 8 - Libeň, Czech Republic

2 Matej Bel University, Faculty of Economics, Tajovského 10, 97590 Banská Bystrica, Slovakia
} 
Clark (1997) stresses that strategic management tools can be applied in all stages of the strategic management process. According to Ramanujam, Venkatraman, and Camillus (1986), Clark and Scott (1999), Frost (2003), and Gunn and Williams (2007) a variety of strategic tools and techniques have been developed to support managers' strategic decisions, often by international consultancy companies (Stenfors et al., 2007).

\section{COMPETITIVENESS}

The present, characterized by globalization, a multitude of technological innovations, high market competition, and increasing administrative and financial burdens, requires high concentration, effort, flexibility in responding to new demands from customers, rapid response to trends and constant seeking to streamline operational processes to ensure the long-term stability and development of businesses operating in the hotel industry.

The development of information and communication technologies and their increasing use has radically changed the relationship between the hotels and their guests. Competitive advantage is based on differentiation and divergence, but the current information-sharing means that hotels must count on the fact that the competition is watching them and will plan something similar.

Competitive performance, or competitiveness, reflects competitive advantages in specific market situations in a given period, whether short or long. Thus, as market conditions change, the distribution of competitive advantages, and thus the competitiveness of individual actors, may also change. The problem, however, is that old habits have long been relatively profitable, reducing motivation to change (Porter 2003).

Competitiveness is a function of dynamic progressiveness, innovation, and the ability to change and improve (Kitson, Martin, Tyler, 2004).

D'Cruz and Rugman (1992) view the competitiveness of a firm as its ability to design, produce, and (or) market products superior to those provided by the firm's competitors, considering both the price and non-price factors. According to Huggins (2000), competitiveness involves productivity, efficiency, and profitability as a means of achieving rising standards of living and increasing social welfare.

Based on the available theoretical background, most of the authors list the similar factors of competitiveness of the companies including hotels, which include physical characteristics, factors determined by the market, and factors that are controllable by the hotel general manager (Morey \& Dittman, 1995; Philips, 1996; Barros, 2005; Brown, 1999; Cizmar \& Weber, 2000; Kim, 2005; Sanchez-Gutierez, 2012; Schmuck, 2008).

Strategic decisions affect hotel productivity and competitiveness (Brown \& Dev (1999). Brown and Dev (1999), Philips (1996), and Morey and Dittman (1995) emphasized the role of the hotel general manager in making strategic decisions following the demand and competitive conditions.

Managers should pay attention to efficient management as it affects the hotel's productivity (Brown \& Dev, 1999; Barros, 2005; Yang \& Lu, 2006; Brown \& Ragsdale, 2002). 
Service quality is another factor that has an essential effect on the performance and competitiveness of the hotel as it can lead to repeated visitation and guest loyalty (Matilla \& O'Neil, 2003; Cardozo, 1965; Fornell, 1992; Halstead \& Page, 1992; Akbaba, 2006.)

Integrating innovation into the strategy is crucial for hotels, as technology can be a way to improve competitiveness (Orfila-Sintes et al., 2005).

Cizmar and Weber (2000) claimed that active marketing activities are positively related to business performance and competitiveness.

Karagiorgas, Tsoutos, \& Moia-Pol, (2007), consider operational costs, in particular, environmental and energy-related costs as a factor of hotel performance and competitiveness.

The professionalism of management, quality, and effective performance of managerial functions, customer orientation, availability of quality human resources, employee-training rate belongs to the most important factors of competitiveness in the Slovak hotel industry. Hotel managers have at their disposal a wide range of modern strategic management tools that they can use to improve the Slovak hotels' competitiveness.

\section{STRATEGIC MANAGEMENT TOOLS}

In 1993, the business-consulting firm Bain \& Company launched a multi-year research project focused on management tools and trends (Rigby \& Bilodeau, 2015). Based on the survey results the most used management tools include Strategic Planning, Customer Relationship Management, Benchmarking, Balanced Scorecard, Core Competencies, Outsourcing, Change Management, Vision and Mission Statements, Customer Satisfaction, Strategic Alliances, Business Process Reengineering, Growth Strategies, Pay per Performance, Customer Segmentation, Scenario and Contingency Planning, Knowledge Management, and Employee Engagement Surveys. The study reveals the correlation between the size of the company and the number of tools used and regional variation in tool use. Transportation and tourism, manufacturing, technology, and telecommunications sectors showed the highest tool use. Taking into account the specifics of the hotel industry and the results of the pilot study in Slovak hotels, the following fourteen tools have been chosen as the object of this study.

Strategic Planning is an essential tool for business executives whose development dates back to the 1950s. This tool implements a well-defined enterprise strategy into crucial business goals and explicitly connects all business goals with daily operation and transform them into deliberate steps that are needed to be achieved (Nolan, 2008). Strategic planning in the current business environment helps the company identify early changes in the external business environment and adapt to them the necessary measures in the future direction and corporate governance. It is a tool that helps managers to learn how to respond to a continually changing business environment (Fogg, 2010).

Customer Relationship Management (CRM) is based on the idea that building a sustainable relationship with customers can help to obtain loyal customers who are much more profitable than non-loyal ones (Dowling, 2002). CRM helps to understand the needs and desires of customers and evaluate the economic efficiency of business collaboration with individual customers based on profitability indicators (Mguyen, Sherif \& Newby, 2007). Based on collected and processed 
data, sales strategies can be created for each product, customers can be segmented according to predefined criteria, the approach can be developed, product and internal processes can be innovated, plan for future earnings, and training program for employees can be created (Peppers, 2011, Sarmaniotis, 2013). Hotels from the nature of its activities collect data on their guests and can transform them into useful knowledge (Lin \& Su, 2003; Nasution \& Mavondo, 2008; Dev $\&$ Olsen, 2000). In a highly competitive global tourism market hotels need to encourage their guest to repeated visitation; thus the implementation of CRM is for hotels an efficient way of enhancing profitability and guest loyalty and improves their competitiveness (Papastathopoulou, Avlonitis \& Panagopoulos, 2007; Verdugo, Oviedo-Garcia \& Roldan, 2009; Sigala, 2005; Wu \& Li, 2011).

Internal Relationship Management represents a tool for measuring satisfaction and meeting the individual needs of employees, working groups, and departments of the enterprise. This management tool is a response to several studies (e.g., Jensen, 2007, Medlin \& Green, 2009) that confirmed a direct dependence between mentally and emotionally recruited employees, the number of loyal customers, and business performance. This tool helps to identify the personal realization of employees in specific positions, their relationship, and links with other employees across the entire organizational structure. The goal of this tool is to reduce employee fluctuation, typical for the hotel industry, identify the right job positions for the right employees, create small working groups and create an appropriate work environment for employees.

When managing a company, mathematical quantification and a combination of data give rise to some indicators that are continually applied. However, proper use and recognition of the importance of these indicators is often a problem for managers. Kaplan and Norton developed the Balanced Scorecard (BSC) management tool that is based on the logic of the management circle: plan-do-check-act (Kaplan \& Norton, 2000). It aims to reduce the information burden on managers and an emphasis on critical financial and non-financial indicators that are crucial to the fulfillment of the corporate strategy (Creamer, 2010) and provides feedback on internal processes and external business outcomes to endlessly modification of strategic performances. It turns strategic planning into the center of an enterprise as soon as it is fully implemented (Kaplan \& Norton, 2000). An advantage of BSC is its universal applicability for a wide range of businesses. It is part of an information system that is available to all employees at different business levels (Laitinen, 2006). Balanced Scorecard was successfully implemented in the hotel industry e. g. in recognized hotel brands as Hilton Hotels and Marriott franchisee White Lodging Services (McPhail, Herington \& Guilding, 2007).

Six Sigma is a proven quality management tool with an emphasis on professional project management (Bisgaard, 2004). It is built on statistical and mathematical techniques and aims to create nearly perfect products or provide impeccable services, results of which are reflected in the improvement of financial indicators of enterprise and increase its market value (Töpfer, 2008). Six Sigma is a comprehensive, flexible management tool that focuses on continuous improvement (innovation) of the organization by understanding customer needs and expectations, by analyzing processes and standardizing measurement methods by the use of information and data for management and decision-making. Goals of Six Sigma included profit maximization, efficient use of resources and increased productivity, reduction of support processes, and minimizing adverse phenomena - defects, mismatches, losses, claims, and costs. Added value from the utilization of Six Sigma may occur in hotels in the following areas: increase in information accuracy; reduction of peak time check-ins/check-outs: elimination of billing errors; reduction 
in the amount of „no-shows”; reduction in housekeeping room turnaround times; standardized cleaning procedures/policies (sixsigmaonline.org, 2017).

Benchmarking is one of the management tools that have been used for a long time. Its popularity explains the simplicity, which is one of the principles of this instrument. Benchmarking is a continuous and systematic process of comparing and measuring products, processes, and methods of an organization with the best in the market to define the goals of improving the organization. Leaders can compare methods and performances externally with businesses within comparable business segments (Harrington, 1996; Boxwell, 1994; Lane, 2016). Benchmarking can be provided as internal - takes place within the institution, when the performance of branches and various organizations is compared; it can also be used to compare the effectiveness of new and old practices in an organization (Camp, 2006); and as external - applied amongst more comparatively large institutions.

Edgar, Litteljohn, Allardyce, Wanhill, Day and Wensley (Edgar, Litteljohn \& Allardyce 1994; Edgar, Litteljohn, Allardyce \& Wanhill, 1994; Edgar, 1997; Day \& Wensley, 1998) state that competitive advantage must create value for guests and guests must perceive it. This value needs to indicate a specific benefit for guests, so they will pay to get it. Such a benefit cannot be easily obtainable elsewhere. Core Competencies are a set of skills, knowledge, and technology that deliver added value to the guests, ensure uniqueness, and make it possible to introduce a range of new products (Hamel \& Prahalad, 1994; Drejer, 2002). Prahalad and Hamel (1990), argue that the primary source of a company's competitive advantage is its ability to innovate based on its core competencies, a conceptually integrated business management tool, the essence of which is to identify and isolate critical strengths of the business and compare them with competitors.

Outsourcing is a widely used management tool. Evald (2012) lists three basic approaches to outsourcing - cost, competency, and relationship. Hotels can benefit from outsourcing regarding reducing the operational risk and cost \& quality control process. Outsourcing aims to decrease the number of operations that are carried out within the hotel (Burn \& Ash, 2000; Georgantzas, 2001), and only functions generating added value and tightly bonded with the hotel's competitive advantage are implemented internally. The benefit hotels receive by outsourcing include focus on core business or competences (Lacity, Hirschheim \& Willcocks, 1994), increased flexibility (Lacity, Willcocks \& Feeny, 1995), improved quality of services and dispose of time-consuming and routine task without added value, or access to technologies, capabilities, and knowledge they do not own (Lee, 2001).

Supplier Relationship Management (SRM) aims to synchronize all factors involved in the process of producing goods or providing services - suppliers, manufacturers, distributors, dealers, and customers, with an emphasis on timely, complete, and efficient customer satisfaction. This tool is based on a sophisticated information system that ensures a close relationship between input and output factors and makes the value chain of goods or services more efficient (Frazelle, 2001). Ayers (2006, p. 16) emphasizes that the synergy of the close relationship is the provision of services or sale of goods to a targeted customer, ,at the right time, at the right place and the right cost." This management tool was a response to changing the business environment, the intensity of communication, the use of new management tools of supply, data storage and utilization, overall consolidation, and the tendency to build strategic partnerships (Trent, 2007). Hotels can benefit from a good relationship with their suppliers, primarily from increased efficiency and optimized performance, cost control, and loyalty. 
Controlling is a result-oriented management tool that integrates traditional accounting with planning into a comprehensive management concept. Includes planning, control, and information flows and is focused on the outcome. The key to control is the calculated prices of products and services. Controlling is not just about cost tracking, but rather a focus on the future, the analysis of the former state and the forecast of the future development of the organization's finances and measures for tomorrow. It utilizes various mathematical and statistical methods for control indicators. Each area where the controlling is applied can be elaborated and analyzed in a very detailed manner based on multiple indicators. Controlling can make a significant contribution to working successfully despite the now intense competition that prevails in the market for hotel services and the increased difficulty in making leadership achievable (Gewald, 2014).

An essential part of the management in the hotel industry is Total Quality Management. TQM is the most complex and comprehensive concept, and its implementation is mostly achieved by gaining experience with the application of the ISO 9000 standards, an integrated philosophy is to manifest itself in all organization activities when the enterprise is involved in continually improving the quality of products and services. It consists of a technical (application of modern tools, methods, and techniques of quality management) and a social subsystem (human factor mobilization).

The EFQM Model of Excellence is a practical tool that helps hotels to understand where they are on the path to Excellence. The model allows organizations defining the gaps and stimulating solutions. It applies to different kinds of organizations regardless of size, structure, ownership, and sector. The results can be used as part of the business planning process, and the model can be used as a rudiment for operational and project review (Llusar, Tena, \& Puig, 2009; Rujsan, 2005). The model was introduced in early 1992 as a management tool that encourages organizational self-assessment. The model is regularly updated and refined and is used by more than 30,000 businesses and organizations.

The Activity-Based Costing (ABC) is originated in the 1980s and is associated with the names of Kaplan, Cooper (Kaplan \& Cooper, 1988; 1997), and Johnson (Johnson \& Kaplan, 1987). At the same time, the first concepts of the $\mathrm{ABC}$ method were presented as methods for assigning overhead costs as well as for measuring and evaluating costs and process performance. Product/ service cost based on the ABC method includes direct costs and the allocated portion of production, but mostly non-production overheads. The total costs of the enterprise are broken down by its activities. Brignall (1997) states that the proportion of fixed costs in the hotel industry is high and uncontrollable. The fundamental purpose of the $\mathrm{ABC}$ calculation is, therefore, to accurately express the cost related to the cause of its occurrence, especially when the increase in costs is not due to the rise in the volume of the final output.

Internet, and especially Social Media, fundamentally changed the hotels and their interaction with guests. The internet plays a growing role also in the European travel sector; $61 \%$ of Europeans use the internet every day or almost every day, $54 \%$ of Europeans say they use Social Media at least once a week, 38\% use them every day or nearly every day (Eurobarometer, 2016). According to ehotelier.com (Cartwright, 2017), Social Media have 2.3 billion active users, while on Facebook is 1.86 billion users active, and 284 million users are active on Twitter. On average, 2.73 million posts are made on blogs every day, and 600 million users are monthly active on Instagram. Ninety-one percent of retail brands use two or more Social Media channels. Users generate the content on Social Media sites, and hence their opinions are more credible to 
potential guests. Ninety-two percent of guests trust word-of-mouth and recommendation from friends and family; online guest reviews are the second most trusted form of advertising.

Social media can affect hotel marketing as they allow to efficiently engaging with guests as well as for brand management purposes. They can improve Customer Relationship Management of the hotels as Social Media often encourages greater transparency in guests' responses and so that hotels can quickly improve their services and positively affect their income in the long-term.

\section{METHODOLOGY}

The study aims to identify the current state of the use of strategic management tools in the hotel industry in Slovakia with a focus on four-star hotels. According to the objective of the study, the following hypothesis was formulated.

Hypothesis One: Managers of the four-star hotels in Slovakia are familiar with all the fourteen selected strategic management tools.

Hypothesis Two: Managers of the four-star hotels in Slovakia do use all the fourteen selected strategic management tools.

The analysis and data represented in this paper are based on primary and secondary research. The study included a review of recent literature and research reports on the use of management tools in the different economic sectors. Data for the analysis were obtained through a questionnaire. The respondents were selected by purposeful sampling. Specific selection criteria as (1) duration of employment in the hotel for five years, (2) and holding management position were determinate to ensure the sample could answer the questions and prove or disprove the hypothesis. From the 183 four-star hotels in Slovakia (SSO, 2017), thirty representatives of the four-star hotels fully met the specific selection criteria. The inquiries were sent to managers via email; the return was $73.3 \%$. The sample was compiled according to data from the Booking. com portal. The criterion of 4 stars, room price over $200 €$, and guest rating over 9.2 was set. It was assumed that in hotels with high guest ratings and price per room higher than $200 €$ is a higher probability of application of the examined strategic management tools. The collected data were processed by mathematical and statistical methods at a significance level of $\alpha=0.05$, with $95 \%$ reliability. The result of the survey was compared with studies focused on the use of management tool utilization conducted in Slovakia and surrounding countries. The survey was conducted from December 2017 to November 2018.

\section{RESULTS AND DISCUSSION}

In recent years, the number of overnight stays in tourist accommodation establishments has generally been increasing. In 2017, the number of overnight stays in accommodation establishments reached 3.1 billion in the European Union.

The number of accommodation establishments in Slovakia was two-thousands seven-hundred seventy-two in 2017 with 186000 beds; the number of overnight stays of residents and non-residents reached 14.7 million with 2.9 nights on average (Eurostat, 2019). The number of nights spent at hotels and similar accommodation establishments was in 2017 in Slovakia 6105767 in 2018, while in the 28EU countries, it was estimated 963434 783. Slovakia's hotels and similar 
accommodation establishments contributed to $28 \mathrm{EU}$ countries' results by $0,634 \%$ (Eurostat, 2019a), which is a low share. In this context, the Slovak hotels need to improve their competitiveness. Hotel managers have at their disposal a wide range of modern strategic management tools that they can apply. Higher-class hotels in Europe apply modern management tools significantly more often than those in Slovakia; this is due to the long tradition of the market mechanism, the size of hotels, and their involvement in international hotel chains. Hotel chains are known for the application of modern management methods and their application. There are nineteen hotel chains present in Slovakia, which operate twenty-eight hotels, including twenty-six four-star and above hotels. Most of the one hundred eighty-three four-star hotels are family-owned.

The following steps were carried out to find out the current state of use and knowledge of the modern strategic management tools in Slovak hotels.

First, the extent to which hotel managers are familiar with strategic management tools was ascertained by the Likert scale from 1 - I do not know to 5 - I know very well. Based on the processed results (Table 1), the knowledge of the Controlling, Strategic Planning, Customer Relationship Management, Benchmarking, Outsourcing, Supplier Relationship Management, and Social Media was reported by the respondents. Management tool as Six Sigma, BSC, and Activity Based Costing was reported as less known. Knowledge of EFQM and TQM was reported in the middle of the scale with the highest standard deviation. It means that some managers know these tools very well, and the others do not know them at all.

Table 1. Knowledge of Management Tools

\begin{tabular}{clccc}
\hline \multicolumn{1}{c}{ Mankagement Tool } & Count & Average & Standard Deviation \\
\hline 1 & Controlling & 22 & 4,09 & 0,92 \\
1 & Strategic Planning & 22 & 3,91 & 0,87 \\
3 & CRM & 22 & 3,73 & 0,77 \\
3 & Benchmarking & 22 & 3,82 & 0,85 \\
3 & Outsourcing & 22 & 3,95 & 1,00 \\
3 & Supplier Relationship Management & 22 & 3,95 & 1,00 \\
3 & Social Media & 22 & 3,77 & 1,07 \\
3 & Internal Relationship Management & 22 & 3,27 & 0,88 \\
9 & TQM & 22 & 2,77 & 1,41 \\
9 & Core Competencies & 22 & 2,73 & 1,20 \\
9 & EFQM Excellence Model & 22 & 2,32 & 1,49 \\
12 & ABC & 22 & 2,23 & 1,19 \\
13 & BSC & 22 & 1,95 & 0,95 \\
14 & Six Sigma & 22 & 1,50 & 0,80 \\
\hline
\end{tabular}

Source: Authors processing

Further, the intensity of use of the same management tools was examined as follows: daily -7 , weekly -6 , monthly -5 , quarterly -4 , yearly -3 , once every three years -2 , never -1 . Based on the results of the Friedman and Wilcoxon test, among the most widely used management tools were recognized, Customer Relationship Management, Social Media, Internal Relationship Management, Outsourcing, Controlling, and Benchmarking were recognized. Total Quality Management, EFQM Excellence Model, Activity Based Costing, Balanced Scorecard, and Six Sigma (Table 2) were not used in any of the studied hotels.

Most of the managers of monitored hotels reported weekly usage of Customer Relationship Management, Social Media, and Internal Relationship Management; monthly application of 
Benchmarking, Outsourcing, and Controlling. The usage of Supplier Relationship Management, Strategic Planning, and Key Competencies were reported on average once a year.

Table 2. Use of Strategic Management Tools

\begin{tabular}{clcc}
\hline Rank & \multicolumn{1}{c}{ Strategic Management Tools } & Median & Standard Deviation \\
\hline 1 & CRM & 5,77 & 1,57 \\
2 & Social Media & 5,46 & 1,68 \\
2 & Internal Relationship Management & 5,59 & 1,50 \\
4 & Outsourcing & 5,14 & 1,52 \\
5 & Controlling & 4,96 & 1,89 \\
5 & Benchmarking & 4,55 & 1,71 \\
5 & Supplier Relationship Management & 4,41 & 1,79 \\
8 & Strategic Planning & 3,64 & 1,47 \\
9 & Core Competencies & 2,36 & 1,71 \\
10 & TQM & 1,00 & 0,00 \\
10 & BSC & 1,00 & 0,00 \\
10 & Six Sigma & 1,00 & 0,00 \\
10 & ABC & 1,00 & 0,00 \\
10 & EFQM Excellence Model & 1,00 & 0,00 \\
\hline
\end{tabular}

Source: Authors processing

Based on the characteristics of management tools, the answer scaling key to the second question in the questionnaire was compiled to determine how many hotels from monitored respondents use or do not use the selected management tools frequently. The minimum frequency of use of the management tool is shown in Table 3. If a hotel less often uses the tool than a specified minimum usage rate, the instrument was considered as unused.

Table 3. Minimum Intensity of Strategic Management Tools Use

\begin{tabular}{clc}
\hline Rank & \multicolumn{1}{c}{ Strategic Management Tool } & Minimum Usage Intensity \\
\hline 1 & CRM & Monthly \\
2 & Social Media & Weekly \\
3 & Internal Relationship Management & Monthly \\
4 & Outsourcing & Monthly \\
5 & Controlling & Monthly \\
6 & Benchmarking & Monthly \\
7 & Supplier Relationship Management & Monthly \\
8 & Strategic Planning & Yearly \\
9 & Core Competencies & Yearly \\
10 & TQM & Unused \\
11 & BSC & Unused \\
12 & Six Sigma & Unused \\
13 & ABC & Unused \\
14 & EFQM Excellence Model & Unused \\
\hline
\end{tabular}

Source: Authors processing

Based on responses scaling, the most used management tools in monitored hotels include Customer Relationship Management and Strategic Planning (used in $86 \%$ of surveyed hotels), followed by Internal Relationship Management, Controlling, Outsourcing, Benchmarking, Social Media and Supplier Relationship Management (Table 4). 
Table 4. Most Used Strategic Management Tools

\begin{tabular}{clcccc}
\hline \multirow{2}{*}{ Rank } & \multirow{2}{*}{ Strategic Management Tools } & \multicolumn{2}{c}{ Used } & \multicolumn{2}{c}{ Not used } \\
\cline { 3 - 6 } & CRM & Count & Share in \% & Count & Share in \% \\
\hline 1 & Strategic Planning & 19 & 86 & 3 & 14 \\
1 & Internal Relationship Management & 19 & 86 & 3 & 14 \\
2 & Controlling & 17 & 82 & 4 & 18 \\
3 & Outsourcing & 16 & 73 & 5 & 23 \\
4 & Benchmarking & 16 & 73 & 6 & 27 \\
4 & Social Media & 15 & 68 & 6 & 27 \\
5 & Supplier Relationship Management & 14 & 64 & 7 & 32 \\
6 & Core Competencies & 10 & 45 & 12 & 36 \\
7 & TQM & 0 & 0 & 22 & 55 \\
8 & BSC & 0 & 0 & 22 & 100 \\
8 & Six Sigma & 0 & 0 & 22 & 100 \\
8 & ABC & 0 & 0 & 22 & 100 \\
8 & EFQM Excellence Model & 0 & 0 & 22 & 100 \\
8
\end{tabular}

Source: Authors processing

The application of Total Quality Management and EFQM Excellence Model, as well as Balanced Scorecard, Six Sigma, and Activity Based Costing, was not reported by respondents.

Gierczak (2014) conducted a similar survey in three- and four-star hotels in the Rzeszów area in Poland in 2012. She found that the most commonly used management tools by managers were Knowledge Management, followed by Outsourcing, Benchmarking, and Internal Competition, respectively. Gierczak (2014, p. 183) concludes, ,the managers significantly lacked substantive knowledge of emerging ,market' management methods and concepts."

Most of the researchers in Slovakia and the Czech Republic focus on their research of usage of strategic management tools on enterprises from different sectors. For example, Šiška and Matýsek (2007) surveyed in the Czech Republic in 2007 on a selected sample of two hundred ninety-one enterprises. Their research aimed to find out what tools and systems the Czech companies use to measure their performance. Based on the results of their study, they found that enterprises in the Czech Republic mainly use Full-cost Management Accounting, combined with principles of Controlling. Total Quality Management and Balanced Scorecard were rarely used.

Karabášová, (as cited in Durkáčová \& Kádárová, 2012) surveyed the usage of selected management tools in one hundred and ten manufacturing enterprises in Slovakia with a turnover of more than 5 million Euros. The results of the survey showed that that the most used management tools include Strategic Planning, Customer Analyses, CRM, Support of Internal Innovation, Price Optimization Models, Core Competencies, Customer Segmentation, Loyalty Maintaining Tools, and Crisis Management.

Based on the results of the survey of 722 manufacturing companies in the Czech Republic and Slovakia, Pawliczek (2013), indicates that the most widely used management tools reported were Total Quality Management, Six Sigma, Core Competencies, and Balanced Scorecard.

Lisiński et al. (2012) presented the results of research conducted in 2011 on the use of modern management concepts in companies in Lesser Poland and Silesia Voivodeships. They surveyed 125 companies operating in the heavy-industry sector. The results of the study confirmed that 
the companies are using strategic management tools; however, in highly diverse mode. To the most used management tools belong Controlling and Outsourcing. Balanced Scorecard and Business Process Reengineering were reported as rarely used by respondents.

Based on the presented results of the primary research, it can be stated that managers in Slovak hotels are familiar with Controlling, Strategic Planning, Customer Relationship Management, Benchmarking, Outsourcing, Supplier Relationship Management, and Social Media. Six Sigma, BSC, and Activity Based Costing are less known as the others. Hypothesis One: Managers of the four-star hotels in Slovakia are familiar with all the fourteen selected strategic management tools was partially confirmed.

Managers use Customer Relationship Management, Social Media, Internal Relationship Management, Outsourcing, Controlling, and Benchmarking; however, they do not apply tools as Total Quality Management, EFQM Excellence Model, Activity Based Costing, Balanced Scorecard, and Six Sigma. Hypothesis Two: Managers of the four-star hotels in Slovakia do use all the fourteen selected strategic management tools was partially confirmed.

The most used management tools in monitored hotels include Customer Relationship Management and Strategic Planning, followed by Internal Relationship Management, Controlling, Outsourcing, Benchmarking, Social Media, and Supplier Relationship Management.

\section{CONCLUSION}

Hotels are operating in a highly competitive market where the offer usually prevails over the demand. In the effort to maximize the profit, management can use a wide range of strategic management tools. Compared to businesses in other sectors of the economy in Slovakia and surrounding countries, hotels are lagging in using strategic management tools. Hotels in Slovakia also need to focus on the quality of services following the new trends in management and implement strategic management tools to increase competitiveness, improve business efficiency and economy, and ability to respond quickly to changing market demands. The positive effects on competitiveness are reflecting the whole tourism sector; this is an essential and decisive contribution to the use of strategic management tools in the hotel industry in Slovakia.

In four-star and above star hotels with only average or above-average occupation rate, the use of strategic management tools is crucial to minimize losses. Implementation of the strategic management tools could also help to avoid short-term process and liquidity crises and to create strong foundations for long-term operation in a challenging competitive environment.

\section{REFERENCES}

Afonina, A. \& Chalupský, V. (2012). The Current Strategic Management Tools and Techniques: The Evidence from Czech Republic, Economics and Management, 17(4), 1535-1544.

Akbaba, A. (2006). Measuring service quality in the hotel industry: A study in a business hotel in Turkey. International Journal of Hospitality Management, 25(2), 170-192.

Ayers, J. B. (2006). Handbook of Supply Chain Management, Boca Raton: Taylor \& Francis Group.

Barros, C. (2005). Measuring efficiency in the hotel sector, Annals of Tourism Research, 32(3), $456-477$. 
Bisgaard, S. \& Freiesleben, J. (2004). Six Sigma and the bottom line, Quality progress, 37(9), 57-62. Boxwell, R. J. (1994). Benchmarking for Competitive Advantage. New York: McGraw-Hill.

Brignall, T. (1997). A contingent rationale for cost system design in services, Management Accounting Research 8(3), 325-346.

Brown, J. \& Dev, C. S. (1999). Looking beyond PevPAR: Productivity consequences of hotel strategies, Cornell Hotel and Restaurant Administration Quarterly, 40(2) 23-33.

Brown, J. R. \&Ragsdale, C.T. (2002). The competitive market efficiency of hotel brands: An application of data envelopment analysis, Journal of Hospitality \& Tourism Research, 26(4), 332-360.

Burn, J. M. \& Ash, C. (2000). Knowledge Management Strategies for Virtual Organizations, Information Resources Management Journal, 13(1), 15-23.

Camp, R. C. (2006). Benchmarking: The Search for Industry Best Practices that Lead to Superior Performance. New York: Productivity Press Publishing.

Cartwright, S. (2017). How the hospitality industry is embracing social media. [online]. [quoted to 03. 07. 2019]. Available at: https://ehotelier.com/insights/2017/04/27/hospitality-industry-social-media/.

Cardozo, R.N. (1965). An experimental study of customer effort, expectation, and satisfaction, Journal of Marketing Research, 2, 244-249.

Cizmar, S. Weber, S. (2000). Marketing effectiveness of hotel industry in Croatia, International Journal of Hospitality Management, 19(3), 227-240.

Clark, D. N. (1997). Strategic Management Tool Usage: A Comparative Study, Strategic Change, $6(7), 417-427$.

Clark, D. N. \& Scott, J. L. (1999). Strategic Level MS/OR Tool Usage in the United Kingdom and New Zealand: A Comparative Survey, Asia-Pacific Journal of Operational Research, 16(1), 35-51.

Creamer, G. et al. (2010). Learning a board of Balanced Scorecard to improve corporate performance, Decision Support Systems, 49(4), 365-385.

D’Cruz, J. \& Rugman, A. (1992). New Concepts for Canadian Competitiveness, A working paper, Canada: Kodak.

Day, G. S. \& Wensley, R. (1998). Assessing Advantage: A Framework for Diagnosing Competitive Superiority. Journal of Marketing, 52(April), 1-20.

Dev, C. S. \& Olsen, M. (2000). Marketing challenges for the next decade, Cornell Hotel and Restaurant Administration Quarterly, 41(1), 41-47.

Dowling, G. (2002). Customer Relationship Management: In B2C Markets, Often Less is More, California Management Review, 44/3, 87-104.

Drejer, A. (2002). Strategic Management and Core Competencies: Theory and Applications. Westport: Quorum Books.

Durkáčová, M., Kádárová, J. (2012). Analýza využívania manažérskych nástrojov aplikovaných v procese zvyšovania výkonnosti podnikov, Transfer inovácií, 5(24), 37 - 41.

Edgar, D. A. (1997). Capacity Management in the Short-break Market, Journal of Contemporary Hospitality Management, 9(2), 55 - 59.

Edgar, D. A., Litteljohn, D. L., \& Allardyce, M. L. (1994). Strategic Clusters and Strategic Space: The Case of the Short-break Market, International Journal of Contemporary Hospitality Management, 6(5), 20 - 26.

Edgar, D. A., Litteljohn, D. L., Allardyce, M. L. \& Wanhill, S. (1994). Commercial Short Break Holiday Breaks - the Relationship Between Market Structure, Competitive Advantage and Performance, In A. V. Seaton (Ed.), Tourism the State of the Art (pp. 383-401), Chichester: John Wiley \& Sons. 
Eurobarometer (2016). Media Use in the European Union, Standard Eurobarometer 86 - Wave EB86.2, Brussels: European Commission, Directorate-General Communication.

Eurostat (2019). Eurostat Statistics explained. Tourism statistics at regional level. [online]. [quoted to 08. 08. 2019]. Available at: https://ec.europa.eu/eurostat/statistics-explained/index. php?title=Tourism_statistics_at_regional_level

Eurostat (2019a). [online]. [quoted to 03. 07. 2019]. Available at: https://appsso.eurostat.ec.europa.eu/nui/submitViewTableAction.do

Evald, M. et al. (2012). Reconsidering outsourcing solutions. European Management Journal, $30(11), 99-110$.

Fogg, D. (2010). Team-Based Strategic Planning: A Complete Guide to Structuring, Facilitating, and Implementing the Process, Scotts Valley: Createspace Independent Publishing Platform.

Fornell, C. (1992). A national customer satisfaction barometer: The Swedish experience. Journal of Marketing, 56(1), 6-21.

Frazelle, E. (2001). Supply Chain Strategy, New York: McGraw-Hill.

Frost, F. A. (2003). The Use of Strategic Tools by Small and Medium- Sized Enterprises: An Australasian Study, Strategic Change, 12(1), 49-62.

Georgantzas, N. C. (2001). Virtual enterprise networks: the fifth element of Corporate Governance, Human System Management, 20(3), 171-188.

Gewald, S. (2014). Hotel-Controlling, Edition Dienstleistungsmanagement, München: Oldenbourg Wissenschaftsverlag.

Gierczak, B. (2014). Management Methods and Concepts for Building Competitive Advantage in Hospitality Companies, Polish Journal of Sport Tourism, 21(3), 178-183.

Gunn, R. \& Williams, W. (2007). Strategic Tools: An Empirical Investigation into Strategy in Practice in the UK, Strategic Change, 16(5), 201-216.

Halstead, D. \& Page, T. J., Jr. (1992). The effects of satisfaction and complaining behavior on consumers repurchase behavior, Journal of Satisfaction, Dissatisfaction and Complaining Behavior, 5, 1-11.

Hamel, G. \& Prahalad, C. K. (1994). Competing for the Future, Boston: Harvard Business School Press.

Harrington, H. J. (1996). The Complete Benchmarking Implementation Guide: Total Benchmarking Management, New York: McGraw-Hill.

Jensen, S. et al. (2007). Optimism and employee performance in the banking industry, Journal of Applied Management and Entrepreneurship, 12(3), 73 - 75.

Johnson, H. T. \& Kaplan, R. S. (1987). The Rise and Fall of Management Accounting, Management Accounting, 68(7), 22-30.

Kaplan, R. S. \& Cooper, R. (1988). Make Cost Right: Make the Right Decisions, Harvard Business Review, 66(5), 96-103.

Kaplan, R. S. \& Cooper, R. (1997). Cost and Effect: Using Integrated Cost Systems to Drive Profitability and Performance, Boston: Harvard Business School Press.

Kaplan, R. S. \& Norton, D. P. (2000). The Strategy-Focused Organization, Boston: Harvard Business Review Press.

Karagiorgas, M., Tsoutsos, T. \& Moia-Pol, A. (2007). A simulation of the energy consumption monitoring in Mediterranean hotels: Application in Greece, Energy and Buildings, 39(4), 416-426.

Kim, H. (2005). The relationship between brand equity and firms' performance in luxury hotels and chain restaurants, Tourism Management, 26(4), 549-560. 
Kotler, P., Berger, R. \& Bickhoff, N. (2015). The Quintessence of Strategic Management, Berlin Heidelberg: Springer.

Lacity, M., Willcocks, L. \& Feeny, D. (1995). IT Outsourcing Maximizes Flexibility and Control, Harvard Business Review, 7(3), 84-93.

Lacity, M., Hirschheim, R. \& Willcocks, L. (1994). Realizing Outsourcing Expectations, Incredible Expectations, Credible Outcomes, Information Systems Management, 11(4), 7-18.

Laitinen, E. K. (2006). Constant growth model of the firm: theoretical analysis of the balanced scorecard, Review of Accounting and Finance, 5(3), 298-315.

Lane, L. (2016). The Power of Benchmarking, Grandville: Lexingford Publishing.

Lee, J-N. (2001). The impact of knowledge sharing, organizational capability and partnership quality on IS outsourcing success, Information \& Management, 38(5), 323-335.

Lin, Y. \& Su, H. (2003). Strategic analysis of Customer Relationship Management - a field study on hotel enterprises, Total Quality Management, 14(6), 715-731.

Lisiński, M., Sroka W., Brzeziński P., Jabłoński A., Stuglik J., 2012, Application of Modern Management Concepts by Polish Companies - analysis of research results, Organizacja, 45(2), 41- 49.

Llusar, J. C., Tena, A. B. \& Puig, V. R. (2009). An Empirical Assessment of the EFQM Excellence Model: Evaluation as a TQM Framework Relative to the MBNQA Model, Journal of Operations Management, 27(1), 1-22.

Matilla, A. S. \& Choi, S. (2006). A cross-cultural comparison of perceived fairness and satisfaction in the context of hotel room pricing, International Journal of Hospitality Management, 25(1), 146-15.

McPhail, R., Herington, C. \& Guilding, C. (2007). Human resource managers' perceptions of applications merit of the balanced scorecard in hotels, International Journal of Hospitality Management, 27(4), 623-631.

Medlin, B. \& Green, K. W. Jr. (2009). Enhancing performance through goal setting, engagement, and optimism, Industrial Management \& Data Systems, 109(7), 943-956.

Mguyen, T. U. H., Sherif, J. S., \& Newby, M. (2007). Strategies for successful CRM implementation, Information Management and Computer Security, 15(2), 102-15.

Morey, R.C. \& Dittman, D.A. (1995). Evaluating a hotel GM's performance: A case study in benchmarking, Cornell Hotel and Restaurant Administration Quarterly, 36(5), 30-35.

Nasution, H. N. \& Mavondo, F. T. (2008). Organizational capabilities: antecedents and implications for customer value, European Journal of Marketing, 42(3-4), 477-501.

Nolan, T. et al. (2008). Applied Strategic Panning: An Introduction. San Francisco: Pfeiffer. Orfila-Sintes, F., Crespi-Cladera, R., \& Martinez-Ros, E. (2005). Innovation activity in the hotel industry: Evidence from Balearic Islands, Tourism Management, 26(6), 851-865.

Papastathopoulou, P., Avlonitis, G. \& Panagopoulos N. G. (2007). Intra organizational information and communication technology diffusion: implications for industrial sellers and buyers, Industrial Marketing Management, 36(3), 322-336.

Pawliczek, A. \& Piszczur, R. (2013). Utilization of modern management methods with special emphasis on ISO 9000 and ISO 14000 in contemporary Czech and Slovak companies. [online]. [quoted to 06. 08. 2019]. Available at: https://dspace.tul.cz/handle/15240/6939.

Peppers, D. et al. (2011). Managing Customer Relationship: A Strategic Framework. New York: Wiley and Sons.

Phillips, P. A. (1996). Strategic planning and business performance in the quoted UK hotel sector: Results of an exploratory study, International Journal of Hospitality Management, $15(4), 347-362$.

Porter, M. (2003). The Economic Performance of Regions, Regional Studies 37(6-7), 549-578. 
Prahalad, C. K. \& Hamel, G. (1990). The Core Competence of the Corporation, Harvard Business Review, 68(3), 79-91.

Ramanujam, V., Venkatraman, N. \& Camillus, J. C. (1986). Multi-objective Assessment of Effectiveness of Strategic Planning: A Discriminant Analysis Approach, Academy of Management Journal, 29(2), 347-372.

Rigby, D. \& Bilodeau, B. (2015). Management Tools and Trends 201, Washington, D. C.: Bain \& Company.

Rujsan, B. (2005). Usefulness of the EFQM Excellence Model: Theoretical Explanation of Some Conceptual and Methodological Issues, Total Quality Management, 16(3), 363-380.

Sanchez-Gutierrez, J. (2012). The effects of intellectual capital and innovation on competitiveness, Hotel and Motel Management, Newton: Questex Media Group, 32 - 46.

Sarmaniotis, A. et al. (2013). Successful implementation of CRM in luxury hotels: determinants and measurements, EuroMed Journal of Business, 2(8), 134-153.

Schmuck, R. (2008). Measuring Company Competitiveness [online]. [quoted to 06. 08. 2019]. Available at: https://core.ac.uk/download/files/153/6504760.pdf

Sigala, M. (2005). Integrating customer relationship management in hotel operations: Managerial and operational implications, International Journal of Hospitality Management, 24(3), 391-413.

Six Sigma Online (2017). The World of Hospitality and Six Sigma. Aveta Limited. [online]. [quoted to 01. 06. 2019]. Available at: https://www.sixsigmaonline.org/six-sigma-training-certification-information/the-world-of-hospitality-and-six-sigma/.

SSO (2017). Basic Indicators of Tourism of the SR for Accommodation Establishments in Year 2016. Bratislava: Slovak Statistical Office.

Stenfors, S., Tanner, L., Syrjanen, M., Seppala, T. \& Haapalinna, I. (2007). Executive Views Concerning Decision Support Tools, European Journal of Operational Research, 181(2), 929-938.

Stonehouse, G. \& Pemberton, J. (2002). Strategic Planning in SMEs-Some Empirical Findings, Management Decision, 40(9), 853-861.

Šiška, L. \& Matýsek, M. (2007). Nástroje měření výkonnosti podniků, Brno: Masarykova univerzita.

Töpfer, A. et al. (2008). Six Sigma, Brno: Computer Press.

Trent, R. (2007). Strategic Supply Management: Creating the Next Source of Competitive Advantage, Plantation: J. Ross Publishing.

Verdugo, C. M., Oviedo-Garcia, A. M. \& Roldan, L. J. (2009). The employee-customer relationship quality: Antecedents and consequences in the hotel industry. International Journal of Contemporary Hospitality Management, 21(3), 251-274.

Wright, R. P., Paroutis, S. E. \& Blettner, B. P. (2013). How Useful Are the Strategic Tools We Teach in Business Schools? Journal of Management Studies, 50(1), 92-125.

Wu, S., Li, P. (2011). The relationships between CRM, RQ and CLV based on different hotel preferences, International Journal of Hospitality Management, 30(2), 262-271.

Yang, C. \& Lu, W. M. (2006). Performance benchmarking for Taiwan's international tourist hotels, INFOR, 44(3), 229-245. 